\title{
IMPLEMENTASI PROGRAM AYO NAIK BUS OLEH PERUM DAMRI BANDUNG
}

\author{
Rizqi Wahyu Pratama ${ }^{1}$, Hanny Hafiar ${ }^{2}$, Centurion Chendy Priyatna ${ }^{3}$, \\ Universitas Padjadjaran
}

\begin{abstract}
This study aims to find out the process of program implementation Ayo Naik Bus by Perum DAMRI Bandung, to determine the cause of the failure of the program Ayo Naik Bus, and to know the communication patterns Perum DAMRI Bandung in overcoming the obstacles that occur in the program Ayo Naik Bus. The theory used in this research is Social Construction theory of Reality. The methodology used is qualitative approach with a case study. The research data was collected by observation, interview, online search, and literature study. The result of this research is the implementation process which originated from the idea of Ministry of Transportation which then implemented into a program by the Marketing and Development division of Perum DAMRI Bandung through special strategies with the aim to increase the interest of Bandung society to use the bus. The results of the implementation of this program are not successful because of the emergence of barriers from external and internal companies that can not be overcome. To find solutions to these problems Perum DAMRI establish a communication pattern with internal and external companies
\end{abstract}

Keywords: Implementation, Program, Perum DAMRI.

\begin{abstract}
ABSTRAK
Penelitian ini bertujuan untuk mengetahui proses pelaksanaan program Ayo Naik Bus, untuk mengetahui penyebab gagalnya program Ayo Naik Bus dan untuk mengetahui pola komunikasi Perum DAMRI Bandung dalam mengatasi hambatan yang terjadi dalam program Ayo Naik Bus. Teori yang digunakan dalam penelitian ini adalah teori Konstruksi Sosial atas Realitas. Metodologi yang digunakan yaitu pendekatan kualitatif dengan studi kasus. Pengumpulan data penelitian dilakukan dengan cara observasi, wawancara, penelusuran online, dan studi pustaka. Hasil dari penelitian ini adalah proses pelaksanaan yang berawal dari gagasan Kementerian Perhubungan yang kemudian dilaksanakan menjadi sebuah program oleh bagian Pemasaran dan Pengembangan Usaha Perum DAMRI Bandung melalui strategi-strategi khusus dengan tujuan untuk meningkatkan minat masyarakat Bandung menggunakan bus. Hasil dari pelaksanaan program ini tidak berhasil karena munculnya hambatan dari eksternal dan internal perusahaan yang belum bisa diatasi. Untuk mencari solusi atas masalah tersebut Perum DAMRI membentuk sebuah pola komunikasi dengan internal dan eksternal perusahaan.
\end{abstract}

Kata Kunci: Implementasi, Program, Perum DAMRI.

\footnotetext{
${ }^{1}$ Rizqi Wahyu Pratama S.I.Kom. email : rizqiwahyupratama@gmail.com

2 Dr. Hj.Hanny Hafiar, M.Si.email : hannyhafiar@gmail.com

${ }^{3}$ Centurion Chendy Priyatna, M.Si.Ph.D. email : centurion.priyatna@gmail.com
} 


\section{PENDAHULUAN}

Pada tahun 2014 jumlah total penumpang bus DAMRI menyentuh angka 10.957.619 penumapng. Lalu kemudian pada tahun 2015 mengalami penurunan penumpang, sehingga pada tahun tersebut penumpang DAMRI hanya sebesar 9.875.588 penumpang. Dan selama periode 2016 ini terhitung dari bulan Januari hingga September jumlah penumpang Damri hanya mencapai angka 5.590.901 penumpang. Jika di rata-rata maka penumpang DAMRI pada tahun 2016 hanya sekitar 600 ribu-an penumpang selama perbulan, berbeda dari tahun sebelumnya yang jika dirata-rata selama per bulan mencapai angka 800 ribu-an penumpang. ${ }^{4}$

$$
\text { Agar menarik minat }
$$

masyarakat dalam menggunakan bus DAMRI lagi Perum DAMRI terus berbenah. Sebagai perusahaan angkutan umum bus plat merah, DAMRI melakukan beberapa pembenahan, terutama pelayanan kepada penumpang. Direktur Keselamatan dan Pelayan Perum DAMRI Gede Pasek Suardika, perbaikan pelayanan dilakukan agar bisa berkontribusi dalam menyiasati kemacetan karena penggunaan

${ }^{4}$ Wawancara Riset di Kantor Perum DAMRI Bandung UABK, Chandra, Staff Bagian Pemasaran dan Pengembangan Usaha Perum DAMRI Bandung 19 September 2017 kendaraan pribadi. Beliau meyakini jika dengan meningkatkan pelayanan banyak orang akan naik bus (Wawancara Riset di Kantor Perum DAMRI Bandung UABK, Chandra, Staff Bagian Pemasaran dan Pengembangan Usaha Perum DAMRI Bandung 19 September 2017).

Perbaikan pelayanan bus DAMRI dikemas dalam program Ayo Naik Bus dengan tagline "biar gak gampang macet dan bikin macet" sesuai dengan tujuan dari peningkatan perbaikan pelayanan yang digagas.Program Ayo Naik Bus ini disosialisasikan kedalam bentuk stiker yang tertara pada kaca samping kiri-kanan dan belakang bus DAMRI agar masyarakat mudah membacanya.

Program Ayo Naik Bus ini kemudian dïmplementasikan ke seluruh wilayah regional. Termasuk perum DAMRI regional Bandung.Perum DAMRI Bandung sendiri tidak ketinggalan dalam meningkatkan kualitas pelayanan.Perubahan paling nampak yang dilakukan adalah peremajaan armada dan kualitas pelayanan yang ditingkatkan.

Kurang lebih hampir selama setahun program perbaikan tersebut telah berjalan semestinya membawa dampak positif bagi Perum DAMRI. 
Namun, berdasarkan situasi yang terjadi dilapangan, program Ayo Naik Bis masih belum memilki dampak signifikan bagi Perum DAMRI cabang Bandung itu sendiri. Menurut data yang peneliti peroleh dari hasil prariset, Perum DAMRI cabang Bandung telah mengalami penurunan jumlah penumpang sejak tahun 2014 silam.

Penerapan program Ayo Naik Bus telah diterapkan oleh Perum DAMRI cabang Bandung untuk mengembalikan kepercayaan masyarakat Bandung untuk menggunakan jasa transportasi mereka, khususnya bus. Ajakan menggunakaan bus tidak hanya terlontar lewat stiker semata yang ditempelkan pada jendela kaca bus, tetapi juga melalui program pemberdayaan komunitas, salah satunya melalui komunitas Pecinta Damri. Pecinta Damri merupakan sekumpulan orang yang peduli akan perkembangan bus DAMRI dan pengguna bus DAMRI itu sendiri. Komunitas ini melalui media sosial mereka juga aktif mengajak kepada seluruh masyarakat untuk menggunakan bus DAMRI dengan tagar \#AyoNaikBis. Tidak hanya mengajak, tetapi komunitas ini juga mensosialisasikan program atau perkembangan bus DAMRI itu sendiri dan mengajak masyarakat untuk disiplin dalam menggunakan fasilitas bus.
Padahal setidaknya terdapat 165 bus baru ber-AC yang merupakan bantuan dari pemerintah melalui Ditjen Perhubungan Darat Kementerian

Perhubungan (Kemenhub) utnuk Perum DAMRI Bandung yang siap beroprasi untuk melayani masyarakat kota Bandung. Sebanyak 142 bus baru akan melayani Cicaheum-Cibeureum, Cibiru-Kebon Kalapa, CicaheumLeuwi Panjang, Ledeng-Leuwi Panjang, dan DipatiukurLeuwipanjang. Kesemua bus baru yang diterima oleh Perum DAMRI Bandung difasilitasi dengan AC sehungga menambah kenyamanan bagi penumpang.

Menurut General Manager
Perum DAMRI Cabang Bandung,
Indra Darmawan, SE. M.Ak., dengan kehadiran ratusan bus tersebut itu, Perum DAMRI terus melakukan berbagai terobosan. Intinya bagaimana agar semuanya mampu berjalan mulus, sehingga membawa dampak positif dan signifikan terhadap sektor transportasi di wilayah Bandung Raya dan Jawa Barat (www.damribandung.com, pada 2 Otober 2016).

Dengan bertambahnya jumlah bus saat ini penumpang tidak perlu lagi menunggu kedatangan bus terlalu lama, yang biasanya bus baru tiba sekitar tiga puluh menit sekali kini dipangkas hanya menjadi lima menit sekali kedatangannya. 


\begin{abstract}
Selain itu pelayanan karyawan juga ditingkatkan.Salah satunya dengan mengadakan pelatihan berupa service excellent sehingga pelayanan yang diberikan maksimum. Mereka dididik dalam hal skill dan kompetensi, termasuk di dalamnya mengenai pola baku dalam pelayanan kepada penumpang serta perawatan armada. Dengan demikian, sekalian mereka nantinya selain akanmemiliki keahlian melebihi pengemudi dan mekanik yang sudah ada, juga diperkuat etika dan hal-hal lainya berkaitan dengan kepuasan konsumen
\end{abstract}

Perbaikan pelayanan yang dilakukan oleh Perum DAMRI secara umum yang diterapkan diseluruh kantor perwakilan Perum DAMRI sendiri yakni antara lain contact center untuk pelayanan penumpang. Contact center itu dinamakan "Hello DAMRI" dengan nomor 1500825. Contact center merupakan jawaban terhadap kebutuhan tanggapan yang cepat atas keluhan, kritik, saran mau pun pertanyaan. Pelayanan dari contact center Hello DAMRI ini akan mengakomodir beberapa hal, antara lain mencari layanan bus DAMRI rute mana pun, keluhan, kritik, ide dan saran perbaikan Perum DAMRI. Perum DAMRI memastikan contact center ini tidak dibebani biaya percakapan. Saat ini operasional contact center baru dari pukul 07.00
WIB hingga pukul 22.00 WIB. Ke depan, operasional contact center akan dilakukan 24 jam.

Perum DAMRI juga akan menerapkan sanksi tegas bagi sopir yang membahayakan penumpang. Salah satu diantaranya menggunakan telepon genggamsaat bertugas. Selain itu, sopir merokok saat mengendari mobil juga akan diterapkan sanksi. Penumpang diminta segera laporkan sopir jika ditemukan melanggar aturan tersebut.

Kelaikan bus menjadi perhatian penting untuk Perum DAMRI. Pengawasan terhadap kelaikan bus akan lebih diketatkan. Sebelum kendaraan beroperasi, kelaiakan bus akan diperiksa secara detil. Sesaat sebelum berangkat pun akan dilakukan pemeriksaan secara acak oleh kantor pusat atau pun regional. Selain itu DAMRI juga melakukan sejumlah peremajaan armadanya dengan armada bus yang baru.

Di Bandung sendiri bus merupakan bagian dari sistem transportasi yang utama dari dulu hingga sekarang.Dan bus DAMRI sudah menjadi bagian dalam sistem transportasi umum yang utama yang ada di kota Bandung dan menjadi andalan masyarakat selama 38 tahun. Tidak adanya moda transportasi massal lain seperti Kereta Api atau Kereta Rel Listrik yang melayani 
warga secara commuter sudah sewajarnya DAMRI menjadi andalan masyarakat dalam aktvitasnya seharihari. Keberadaan Perum DAMRI unit angkutan bis kota Bandung berdasarkan Surat Keputusan No.10/85/76 tanggal 17 Mei 1976, dan mulai beroperasi pada tanggal 22 Juni 1978 setelah mendapat ijin walikota Bandung. Saat ini perum DAMRI Bandung melayani kurang lebih sebelas trayek dalam kota Bandung.

Ayo Naik Bis semestinya menjadi program yang membuat masyarakat kembali mengingat betapa pentingnya menggunakan transportasi umum.Mengurangi kemacetan, jauh lebih murah dibanding menggunakan kendaraan pribadi, memberikan rasa aman, serta terlebih lagi sekarang DAMRI memberikan kenyamanan dengan perbaikan kualitas armada dan pelayanannya.Berdasarkan

pemaparan diatas penulis ingin mengetahui bagaimana implementasi program Ayo Naik Bus oleh Perum DAMRI Bandung untukmengajak masayarakat Bandung menggunakan bus sebagai moda transportasi.

\section{TINJAUAN PUSTAKA}

Peneliti membandingkan
dengan beberapa penelitian sejenis yang juga membahas tentang seuatu program. Tujuannya untuk mengetahui penelitian-penelitian yang membahas tentang sebuah program Public Relations (PR) dengan objek yang berbeda-beda.

1) Putri Tian Lupita Sari, membahas mengenai program Pemberdayaan Kontraktor Lokal TOTAL E\&P Indonesie. Penelitian ini mengkaji tentang bagaimana program Pemberdayaan Kontraktor Lokal sebagai salah satu kegitan Community Development TOTAL E\&P Indonesie. Tujuan dari penelitian ini adalah untuk mengetahui latar belakang dan pelaksanaan Program Pemberdayaan Kontraktor Lokal sebagai salah satu kegiatan Community Development TOTAL E\&P Indonesie (TEPI), serta pemahaman program tersebut oleh tim SDS/EKS/CER selaku pelaksana program dan kontraktor lokal selaku peserta program. Metode yang digunakan pada penelitian ini adalah metode kualitatif dengan pendekatan studi kasus, serta menggunakan teori konstruksi sosial atas realitas.Pengumpulan data yang digunakan adalah melalui observasi, wawancara, dokumentasi, dan studi pustaka.

Hasil penelitian ini menunjukkan bahwa TEPI membuat Program Pemberdayaan Kontraktor Lokal atas dasar adanya keinginan untuk melindungi wilayah 
operasional perusahaan akibat adanya gejolak sosial yang ada di masyarakat. Pemamaham yang dimiliki oleh tim SDS/EKS/CER dan kontraktor lokal terkait Profram Pemberdayaan Kontraktor Lokal hampir serupa, yaitu sama-sama memahami bahwa program ini ada untuk melindungi wilayah kegiatan operasional perusahaan dengan memfasilitasi apa yang menjadi keinginan masyarakat terutama untuk menjadi mitra kerja TEPI. Pelaksanaan Program tidak sematamata langsung dilaksanakan, tetapi melalui perencanaan, impelmentasi, dan evaluasi.

2) Rizki Rianti Y. K. membahas mengenai program Pertamina Mengajar sebagai Kegiatan Fungsi Internal Komunikasi. Penelitian ini mengkaji bagaimana program Pertamina Mengajar sebagai Internal Communication Engagement. Tujuan penelitian ini adalah untuk mengetahui kegiatan Pertamina Mengajar menjadi bagian dari kegiatan Divisi Internal Komunikasi, untuk mengetahui proses Internal Communication Engagement yang terjadi dalam Program Pertamina Mengajar, untuk mengetahui pengalaman dari Program Pertamina Mengajar bagi pihak internal PT Pertamina (Persero). Metode yang digunakan pada penelitian ini adalah metode penelitian kualitatif dengan pendekatan studi kasus, serta menggunakan Teori Interaksi Simbolik dan Teori Konstruksi Sosial Atas Realitas.Data penelitian diperoleh melalui observasi, wawancara, dan studi pustaka.

Hasil penelitian ini adalah pihak internal perusahaan dapat belajar untuk menjalin komunikasi di dalam publik internal perusahaan.Dalam Program Pertamina Mengajar inilah pihak internal dapat meningkatkan softskill mereka di bidang komunikasi yang bermanfaat bagi para jajaran Top Level Management untuk menjalin hubungan dengan pihak internal maupun eksternal demi kemajuan perusahaan. Misi internal communications engagement yang terkandung dalam Program Pertamina Mengajar ini dapat dirasakan oleh karyawan dan jajaran Top Level Management perusahaan melalui kegiatan komunikasi informal dan formal, gathering outside, koordinasi dan kerjasama, serta komunikasi intens yang terjalin selama pelaksanaan program.

3) Elenka Fourtiena Rajagukguk, membahas mengenai program Kampanye Anti Korupsi PT. Pertamina (Persero) Melalui Sistem Pengendalian Gratifika. Penelitian ini bertujuan untuk mengetahui bagaimana latar belakang dan tujuan Kampanya Anti Korupsi PT. Pertamina (Persero) melalui Sistem Pengendalian Gratifikasi, bagaimana 
implementasi budaya GCG di kalangan isan Pertamina, Pemahaman fungsi Compliance terhadap Kampanye Anti Korupsi PT. Pertamina (Persero) melalui sistem Pengendalian Gratifikasi dan bagaimana proses komunikasi yang dilakukan dalam kampanye anti korupsi PT. Pertamina (Persero) melalui Sistem Pengendalian Gratifikasi. Penelitian ini menggunakan metode penelitian kualitatif dengan pendekatan studi kasus dan paradigma konstruktivisme. Teori yang digunakan dalam penelitian ini adalah Teori Konstruksi Sosial atas Realitas oleh Peter L. Berger dan Thomas Luckman. Data pada peneliitia ini diperoleh melalui hasil wawancara mendalam, observasi, studi pustaka, dan dokumentasi.

Hasil penelitian menunjukan bahwa pentingnya reputasi bagi Pertamina untuk mewujudkan transformasi fundamental dengan budaya kerja yang bersih di kalangan pekerja untuk membangun hubungan baik dengan seluruh stakeholder. Melalui kampanye ini diharapkan Pertamina dapat membentuk pekerja yang berintegritas, bersih dan beretika sesuai dengan prinsip GCG.

4) Annisa Ekalestari Putri, membahas mengenai program 1000 Perahu Sapu Bersih Waduk Cirata di Desa Tegaldatar Kecamatan Manis. Penelitian untuk mengetahui bagaimana latar belakang dan pelaksanaan program 1000 Perahu Sapu Bersih Waduk Cirata, serta pemahaman program tersebut oleh Staf Badan Pengelola Waduk Cirata. Metode yang digunakan dalam penelitian ini adalah metode kualitatif dengan jenis studi pendekatan K. Yin dan Teori Stakeholder Freeman, dan juga Teori Konstruksi Sosial atas Realitas Peter Beger dan Luckman. Teknik pengumpulan data yang digunakan yaitu melalui wawancara mendalam, observasi partisipasif, pengumpulan data melalui dokumen, dan triangulasi sumber.

Hasil penelitian ini menunjukan bahwa staf Badan Pengelola Waduk Cirata (BPWC) melaksanakan program tersebut karena adanya permasalahan pencemaran lingkungan di Waduk Cirata oleh aktivitas petani Kelompok Jaring Apung (KJA), sampah eceng gondok dan sedimentasi waduk. Pemahaman program 1000 Perahu Sapu Bersih Waduk Cirata bagi staf BPWC adalah sebagai moment untuk membersihkan waduk secara masal, hal tersebut diperoleh berdasarkan realita yang ada serta pengalaman dimiliki masing-masing staf. Pelaksanaan program tersebut tidak semata-mata langsung dilaksanakan, tetapi melalui beberapa proses PR, seperti yang dikemukakan oleh 
Cutlip, Center dan Broom, yaitu: defining public relations PRoblem, planning and PRogramming, taking action and communication, dan evaluating the PRogram.

$\begin{array}{llr}\text { 5) Ratri } & \text { Gumelar. Membahas } \\ \text { mengenai } & \text { program } & \text { Pelayanan }\end{array}$ Kesejahteraan Lansia di UPT Panti Wredha Budhi Dharma Kota Yogyakarta. Penelitian ini untuk mengetahui sejauh mana kondisi program pelayanan kesejahteraan lansia di UPT Panti Wredha Budhi Dharma kota Yogyakarta, untuk mengetahui secara mendalam pengaruh terhadap peningkatan kesejahteraan lansia, dan untuk mengetahui hambatan yang dihadapi dalam pelaksanaan program pelayanan kesejahteraan di UPT Panti Wredha Budhi Dharma. Metode yang digunakan dalam penelitian ini menggunakan jenis penelitian kualitatif dengan pendekatanstudi kasusK.Yin.Teknik Pengumpulan data yang digunanakan dengan metode wawancara, observasi, dan dokumentasi.

Hasil dari penelitian ini menyatakan bahwa peningkatan kesejahteraan sosial lansia dalam kaitannya dengan program kegiatan di UPT Panti Wredha Budhi Dharma kota Yogyakarta kurang terealisasikan dengan baik karena kondisi fisik lansia satu dan lainnya itu tidak sama. Berdasarkan temuan penelitli di lapangan bahwa program yang diadakan pihak panti tidak menjadikan salah satu faktor utama dalam peningkatan kesejahteraan sosial. Antara pihak satu dan lainnya berbeda-beda dalam menyikapi program kegiatan yang dilakukan dari pihak panti.Karena keterbatasan kondisi fisik dan mental pada akhirnya tidak semua program terlaksana dengan baik, artinya semua kegiatan tidak dapat diikuti bersama, hanya kegiatan tertentu saja.

Peneliti menggunakan teori kontsruksi sosial atas realitas milik Peter Berger dan Thomas Luckman dalam buku Sosiologi Kontemporer karangan Margaret M. Poloma. Menurut teori ini, identitas suatu objek merupakan hasil dari bagaimana kita membicarakan objek bersangkutan, bahasa yang digunakan untuk menuangkan konsep kita, dan cara bagaimana kelompok sosial memberikan perhatiannya kepada pengalaman bersama mereka.

Berger dan Luckmann mengatakan institusi masyarakat tercipta dan dipertahankan atau diubah melalui tindakan dan interaksi manusia. Meskipun masyarakat dan institusi sosial terlihat nyata secara objektif, pada kenyataan semuanya dibangun dalam definisi subjektif melalui proses interaksi. Objektivitas baru bisa terjadi melalui penegasan berulang-ulang yang diberikan oleh orang lain yang memiliki definisi 
subjektif yang sama. Pada tingkat generalitas yang paling tinggi, manusia menciptakan dunia dalam makna simbolik yang universal, yaitu pandangan hidupnya yang menyeluruh, yang memberi legitimasi dan mengatur bentuk-bentuk sosial serta memberi makna pada berbagai bidang kehidupannya (Bungin, 2011: 195).

Jadi sebenarnya yang dimaksudkan oleh Berger dan Luckmann adalah telah terjadi dialektika antara individu menciptakan masyarakat dan masyarakat menciptakan individu. Dialektika ini terjadi melalui proses simultan, yaitu (1) eksternalisasi (penyesuaian diri) dengan dunia sosiokultural sebagai produk manusia, (2) objektivasi, yaitu interaksi yang terjadi dalam dunia intersubjektif yang dilembagakan atau mengalami proses institusionalisasi, dan (3) internalisasi, yaitu proses yang mana individu mengidentifikasikan dirinya dengan lembaga-lembaga sosial atau organisasi sosial tempat individu menjadi anggotanya (Bungin, 2010: 83). Proses tersebut berlangsung di dalam kehidupan masyarakat secara simultan dengan cara membentuk pengetahuan masyarakat.

Menurut Berger dan Luckmann, pengetahuan masyarakat yang dimaksud adalah realitas sosial masyarakat. Realitas sosial tersebut adalah pengetahuan yang bersifat keseharian yang hidup dan berkembang di masyarakat seperti konsep, kesadaran umum, wacana publik, sebagai hasil dari konstruksi sosial. Realitas soial dikonstruksi melalui proses eksternalisasi, objektivasi, dan internalisasi. Menurut Berger dan Luckmann, konstruksi sosial tidak berlangsung dalam ruang hampa, namun sarat dengan kepentingan-kepentingan (Bungin, 2003: 7)

\section{METODOLOGI}

Penelitian ini menggunakan tipe pendekatan studi kasu John W. Cresswell mengungkapkan (2007:61) bahwa sebuah studi kasus adalah suatu eksplorasi dari "sistem dibatasi" atau kasus (kasus multiple) dari waktu ke waktu melalui pengumpulan rinci, mendalam data yang melibatkan berbagai sumber informasi yang kaya dalam konteks.

Jenis dari studi kasus kualitatif dikemukakan berdasarkan ukuran dari suatu kasus yang terikat, kasus tersebut dapat melibatkan suatu individual, beberapa individual, kelompok, program, atau aktivitas. (Creswell, 2007:74). Di dalam penelitian ini, jenis studi kasus yang diteliti yaitu merupakan penelitian terhadap suatu program. Peneliti meneliti salah satu kegiatan Public Relations yaitu Program Ayo Naik Bus dimana Perum DAMRI Bandung berusaha menarik minat masyarakat Bandung untuk menggunakan bus DAMRI. Ajakan ini sekaligus langkah sosialisasi Perum DAMRI kepada masyrakat 
Bandung terkait pembenahan layanan yang telah mereka lakukan. Pembenahan layanan sendiri dilakukan agar meningkatnya citra Perum DAMRI Bandung sebagi salah satu operator transportasi darat dikota Bandung. Dengan meningkatnya citra positif diharapakan jumlah penumpang yang menggunakan bus DAMRI bertambah.

Pada penelitian ini, sampel dan informan diambil menggunakan purposive sampling. Teknik purposive sampling merupakan teknik pengambilan sumber data dengan pertimbangan tertentu pertimbangannya adalah kriteria yang telah ditentukan oleh peneliti (Sugiyono, 2009:300). Teknik purposive sampling digunakan karena peneliti ingin mengidentifikasikan jenis kasus tertentu untuk investigasi mendalam. Tujuannya yaitu untuk mendapatkan pemahaman yang lebih mendalam pada objek penelitian.

Informan penelitian dipilih berdasarkan kriteria atau criterion sampling. Hal ini bertujuan agar data yang diperoleh merupakan data yang akurat dan berasal dari individuindividu yang benar-benar menguasai permasalahan.Sesuai dengan tujuan penelitian kualitatif, yaitu informative richness (Patton, 2002:230).
Informan merupakan orangorang yang terlibat dan merasakan dampak dari Program Ayo Naik Bus Perum DAMRI Bandung. Terdapat kriteria yang dipilih meliputi ketersediaan narasumber untuk dimintai wawancara, kemampuan untuk menjelaskan, dan pemahaman mengenai Program Ayo Naik Bus. Dalam memilih subjek penelitian pada penelitian kualitatif lebih berdasarkan pada alasan-alasan yang disesuaikan dengan tujuan penelitian.

Partisipan secara keseluruhan dalam penelitian ini adalah orangorang yang terlibat dalam Program Ayo Naik Bus yang berasal dari Manager Usaha, Manager Pemasaran dan Pengembangan Usaha, staff Manager Pemasaran dan Pengembangan Usaha, Ketua Komunitas Pecinta DAMRI, Dinas Perhubungan Kota Bandung, dan Penumpang DAMRI. Pemilihan responden dalam penelitian ini bertujuan untuk mendapatkan informasi dan pengalaman yang beragam dalam proses dilaksanakannya Program Ayo Naik Bus dalam menarik minat masyarakat untuk menggunakan bus. Informan dianggap dapat mewakili data dan informasi yang ingin ditelaah oleh peneliti tentang kegiatan, proses, dan hasil dari penelitian. Teknik pengumpulan data merupakan langkah yang paling strategis dalam penelitian, karena 
tujuan utama dari penelitian adalah mendapatkan data. Pengumpulan data dapat dilakukan dalam berbagai setting, berbagai sumber, dan berbagai cara (Sugiyono, 2009:62). Teknik pengumpulan data yang dilakukan pada penelitian ini yaitu menggunakan wawancara mendalam, observasi, dan studi pustaka.

Peneliti

melakukan

wawancara mendalam terhadap

Manager Usaha Perum DAMRI

Bandung selaku orang yang menjalankan salah satu kegiatan

Public Relations melalui Program Ayo Naik Bis. Dalam penelitian ini peneliti juga mengamati secara langsung seperti perubahan yang ada di Perum DAMRI. Peneliti juga menggunakan bus DAMRI serta mengamati perubahan-perubahan pelayanan seperti apa yang diberikan Perum DAMRI Bandung agar masyarakat merasa nyaman menggunakan jasa mereka. Peneliti menngunakan beberapa sumber buku yang terkait dengan penelitian yang dilakukan oleh peneliti sebagai sumber rujukan untuk memperkuat temuan yang dilakukan peneliti. Mulai dari buku-buku bertemakan transportasi, serta buku dan karya ilmiah yang bermuatan tentang aktivitas PR baik itu sumber tercetak ataupun melalui penelusuran melalui internet.

Untuk memeriksa keabsahan
data pada responden, dalam

penelitian ini, peneliti akan menggunakan triangulasi dengan sumber. Triangulasi sumber untuk menguji kredibilitas data dilakukan dengan mengecek data yang telah diperoleh melalui beberapa sumber. (Sugiyono, 2009:370). Dalam penelitian ini yang akan menjadi sumber triangulasi adalah key informan, yakni warga Bandung yang merasakan perubahan yang terjadi sebelum dan sesudah program Ayo Naik Bus ini. Teknik ini membandingkan dan memeriksa secara silang konsistensi informasi yang didapatkan pada waktu dan cara yang berbeda. Peneliti melakukan penelitian ini bertempat di kantor Perum DAMRI Unit Angkutan Bus Kota Jalan Soekarno Hatta no. 787 Gede Bage, Bandung. Penelitian ini dilakukan sejak September 2016 hingga April 2017.

\section{HASIL}

Berdasarkan hasil yang didapat, program Ayo Naik Bus merupakan sebuah program yang digagas oleh Kemenhub, kemudian diimplementasikan oleh Perum DAMRI Bandung dengan cara-cara yang dikemas oleh Perum DAMRI Bandung untuk meningkatkan minat masyarakat Bandung. Tahap berikutnya merupakan tujuan dari program,tujuan alasan mengapa Perum DAMRI Bandung membuat Ayo Naik Bus menjadi sebuah 
program adalah untuk meningkatkan minat masyarakat Bandungagar mereka menggunakan armada Perum DAMRI lagi sebagai moda transportasi dan secara tidak langsung hal ini dapat mengembalikan kredibilitas Perum DAMRI di mata masyarakat Bandung sebagai moda transportasi publik yang terpercaya.Agar program dapat berjalan dengan baik dan tujuan dapat tercapai, Perum DAMRI membuat strategi berupa pengadaan bus baru, efektifitas pelayanan dan penyebaran informasi melalui publik eksternal perusahaan.Dan tahap akhir dari pelaksanaan program ini adalah hasil yang dicapai, pada program ini hasil yang dicapai adalah berupa kegagalan, karena tujuan dari program yang dilaksankan ini belum tercapai.

Masalah utama dari tidak berhasilnya program ini adalah tidak sempurnanya masayarakat Bandung menerima informasi tentang perubahan perbaikan pelayanan yang dilakukan oleh Perum DAMRI Bandung. Sumber dari timbulnya masalah atau hambatan ini berasal dari internal dan eksternal perusahaan.Masalah yang timbul dari internal perusahaan sendiri yakni disebabkan oleh tidak adanya riset serta minimnya publikasi karena terbatasnya jumlah anggaran yang diterima. Lalu dari masalah yang timbul dari eksternal perusahaan adalah karena komunitas Pecinta DAMRI tidak cukup hanya melakukan penyebaran informasi melalui media sosial saja, terlebih masih banyak juga masyarakat yang belum mengetahui tentang komunitas Pecinta DAMRI itu sendiri. Jadi informasi yang disebar hanya sampai kepada mereka yang memang sudah biasa menggunakan DAMRI dan anggota komunitas mereka saja.

Dalam mengatasi hambatanhambatan yang terjadi dalam program Ayo Naik Bus ini peneliti menyimpulkan bahwa pola komunikasi yang dilakukan Perum DAMRI Bandung mengedepankan komunikasi dua arah antara pihakpihak yang berkaitan, baik itu pihak internal maupun eksternal perusahaan. Komunikasi yang dijalin dimaksudkan untuk menyampaikan perkembangan informasi terkait program yang berjalan agar timbul kesepahaman diantara pihak-pihak tersebut. Berdasarkan hasil evaluasi dan berbagai pertimbangan beberapa strategi program yang berjalan harus dihentikan karena dirasa tidak menguntungkan. Maka cara terbaik bagi Perum DAMRI Bandung mengatasi hambatan yang terjadi adalah dengan cara tidak melanjutkan beberapa kebijakan strategi dalam progam Ayo Naik Bus ini dengan tujuan untuk menghindari perusahaan dari kerugian. 


\section{PEMBAHASAN}

Program Ayo Naik Bus ini memliki karakteristik sendiri, terlebih ini baru pertama kalinya dilakukan oleh Perum DAMRI Bandung dalam melakukan aktifitas public relations. Peneliti kemudian meneliti bagaimana program ini berjalan sebagai sebuah bentuk aktifitas public relations dengan pendekatan studi kasus.

Dalam penelitian ini fokus utamanya merupakan Program Ayo Naik Bus yang dilakukan oleh Perum DAMRI Bandung dimana Perum DAMRI Bandung merupakan operator penyedia jasa transportasi darat yang ada di Bandung ingin meningkatkan minat masyarakat Bandung untuk menggunakan bus, khususnya bus DAMRI sebagai salah satu penyedia jasa layanan transportasi darat yang ada di Bandung, mengingat posisi Perum DAMRI Bandung selama lima tahun terakhir sedang mengalami penurunan. Dalam penelitian ini peneliti menggali fenomena tertentu dalam suatu waktu, serta mengumpulkan informasi secara mendalam dan terperinci selama periode tertentu.

Bagian Pemasaran dan Pengembangan Usaha merupakan bagian yang bertanggung jawab dengan segala bentuk pemasaran yang ada di Perum DAMRI cabang
Bandung ini.Perum DAMRI cabang Bandung sendiri tidak memiliki bagian Public Relations, sehingga program yang semestinya dijalankan oleh seorang praktisi Public Relations dijalankan oleh bagian ini.

Menurut Jefkins yang dikutip oleh Rachmadi dalam bukunya menyatakan bahwa humas adalah sesuatu yang menerangkan keseluruhan komunikasi yang terencana, baik itu yang keluar maupun yang ke dalam antara suatu organisasi dengan semua khalayaknya dalam rangka mencapai tujuan-tujuannya spesifikasi yang berdasarkan pada saling pengertian.(1994:18). Definisi tersebut adalah suatu rangkaian kegiatan yang diorganisasikan sedemikian rupa sebagai suatu rangkaian kampanye atau program terpadu dan semuanya itu berlangsung secara berkesinambungan dan teratur mengidentifikasikan bahwa humas harus menggunakan metode manajemen berdasarkan tujuan.

Rangkaian kegiatan tersebut dapat dilihat dari apa yang dilakukan Bagian Pemasaran dan Pengembangan Usaha Perum DAMRI Bandung melalui program Ayo Naik Bus untuk mempersuasi masyarakat kota Bandung sebagai khalayak dengan tujuan untuk mengambalikan kembali minat masyarakat Bandung untuk 
menggunakan bus DAMRI agar kredibilitas Perum DAMRI Bandung sebagai operator penyedia jasa transportasi di Bandung kembali sehingga dapat menciptakan citra positif dimata masyarakat Bandung. Pada penelitiin ini peneliti menelaah keseluruhan bagaimana program Ayo Naik Bus ini dijalankan oleh Perum DAMRI Bandung sebagai program untuk meningkatkan kembali minat masyarakat Bandung untuk menggunakan bus DAMRI. Adapun prosesnya pelaksanannya sebgai berikut :

1. Awal Pembentukan Program

Pada tahap awal dari proses program Ayo Naik Bus ini adalah mengenai identitas dan perencanaan program yang dilaksanakan oleh Perum DAMRI Bandung. Pada tahap ini Perum DAMRI Bandung menerima instruksi dari kantor Pusat untuk melaksanakan program yang digagas oleh Kemenhub.

\section{Tujuan Program}

Sebuah program haruslah memiliki tujuan agar jelas untuk apa sebuah program dilaksanakan. Melalui program Ayo Naik Bus ini Perum DAMRI Bandung bertujuan untuk meningkatkan minat masyarakat Bandung agar timbul keinginan untuk menggunakan bus, khusunya bus DAMRI. Setelah timbulnya minat, akan ada keinginan serta kemauan bahkan tindakan masyarakat Bandung untuk menggunakan bus. Berawal dari timbulnya minat ini Perum DAMRI Bandung berharap tercipta sebuah perbaikan kredibilitas Perum DAMRI Bandung di mata masyrakat Bandung.

\section{Strategi Program}

Dalam proses pelaksanaan program peneliti menemui tiga strategi yang digunakan pihak Perum DAMRI Bandung dalam melaksnakan program Ayo Naik Bus. Strategi tersebut diantaranya adalah peremajaan armada, efektifitas pelayanan dan penyeberan informasi melalui pihak eksternal perusahaan. Dipilihnya strategi tersbut bukannya tanpa alasan tetapi berdasarkan pertimbangan kebutuhan serta kemampuan Perum DAMRI Bandung.

Perum DAMRI bekerjasama dengan publik ekternal mereka yakni Perum DAMRI Bandung untuk meneyebarkan informasi tersebut kepada masyarakat Bandung khususnya.Pengertian publik eksternal merupakan pihak yang tidak berkaitan langsung dengan perusahaan seperti pers, pemerintah, pendidik/dosen, pelanggan, komunitas dan pemasok (Ardianto, 2007:15). Dalam hal ini publik eksternal Perum DAMRI adalah Komunitas Pecinta DAMRI.Alasan Perum DAMRI memilih Komunitas 
Pecinta DAMRI adalah karena mereka menilai bahawa Komunita Pecinta DAMRI pihak yang dekat dengan mereka maupun masyarakat karena anggota komunitas tersebut terdiri dari berbagai latar belakang lapisan masyarakat.

$\begin{array}{lrrr} & \text { Media } & \text { sosial } & \text { merupakan } \\ \text { media } & \text { dipilih } & \text { oleh } & \text { Komunitas } \\ \text { PecintaDAMRI } & & \text { untuk }\end{array}$ menyebarakan informasi ini. Selain karena jumlah follower ataupun interaksi yang dilakukan sosial media komunitas Pecinta DAMRI terhadap khalayak di dunia maya lebih banyak menjadi alasan dipilihnya sebagai media dalam proses penyebaran informasi, sosial media saat ini sudah menjadi kebutuhan masyarakat tidak lagi menjadi sekedar media komunikasi semata.

Menurut Breakenridge sosial media kini tidak lagi sekedar jejaring sosial, namun telah menjelma menjadi sebuah media berbisnis.Media sosial mengajak penggunanya untuk merubah pikiran untuk menggabungkan komunikasi dan kolaborasi teknologi (Breakenridge, 2012: 2).

Dalam penelitian ini bisa dilihat bagaimana Perum DAMRI melalui Komunitas Pecinta DAMRI menginformasikan keunggulan pelayanan mereka serta memberikan stimulus kepada masyarakat agar timbul keinginan untuk menggunakn bus DAMRI misalnya dengan cara memposting sebuah gambar misalnya melalui media sosial Instagram yang isinya berupa interior bus yang nyaman ataupun info berupa kesan-kesan penumpang yang telah menggunakn bus, serta tidak lupa mencantumkan hashtag \#AyoNaikBus.

\section{Hasil Program Ayo Naik Bus} Setelah melakukan tahapantahapan diatas hasil program merupakan tahap akhir dari proses pelaksanaan program Ayo Naik Bus. Hasil program ini merupakan hasil dari evaluasi dari program yang telah berjalan.

Menurut Kasali (1994; 33) tahap ini akan melibatkan pengukuran hasil tindakan di masa lalu. Penyesuaian dapat dibuat dalam proses yang sama, atau setelah suatu masa berakhir. Pengukuran ini menjawab pertanyaan: "How did we do?".

Berdasarkan hasil olah perhitungan pencapain target di tahun sebelumnya dari bulan ke bulan, program Ayo Naik Bus belum menimbulkan dampak yang signifikan bagi Perum DAMRI Bandung. Pihak DAMRI Bandung telah mengakui bahwa program yang telah mereka lakukan ini terbilang gagal.

Identifikasi Proses Eksternalisasi 
Pada tahap eksternalisasi dalam penelitian ini ditunjukkan dari pandangan masyarakat kota Bandung terhadap Perum DAMRI. Dalam kurun waktu lima tahun terakhir kebelakang masyarakat kota Bandung mulai meninggalkan bus DAMRI sebagai moda transportasi. Bus-bus DAMRI sering dikambing hitamkan sebagai penyumbang polusi udara dan kemacetan disekitar mereka akibat dari asap hitam pekat dari knalpot armada mereka serta seringnya armada mereka yang mogok ditengah lalu lintas kota Bandung yang padat ataupun seringkali ngetem terlalu lama. Saat itu armada Perum DAMRI belum seperti saat ini (menggunakan livery baru dan pola tempat duduk yang berbeda). Kondisi bus secara eksterior dapat dikenali dengan warna cat yang saat itu dominasi warna puth dengan kelir biru untuk bus non-AC dan warna biru muda dengan kombinasi putih untuk bus AC.

\section{Identifikasi Proses Objektivikasi}

Proses objektivikasi dalam penelitian ini adalah ketika berjalannya sebuah program Ayo Naik Bus yang dijalankan oleh Perum DAMRI Bandung. Bagi Perum DAMRI Bandung program ini tidak hanya sekedar untuk mengajak masyarakat menggunakan transportasi umum, tetapi juga bertujuan untuk mengembalikan citra dan kredibilitas mereka sebagai penyedia jasa moda transportasi darat yang ada di Bandung. Dengan adanya program ini Perum DAMRI Bandung menjadikannya sebuah momentum untuk berubah dan berbenah dengan begitu berharap masyarakat Bandung akan kembali percaya menggunakan jasa mereka setelah dalam lima tahun belakang ini Perum DAMRI mengalami penurunan jumlah penumpang. Upaya-upaya pun dilakukan Perum DAMRI agar program Ayo Naik Bus ini berhasil dan memberikan dampak positif bagi mereka. Upaya tersebut berupa sebuah strategi untuk menimbulkan kesadaran dan menggugah rasa penasaran masyarakat atas perubahan dan perbaikan yang telah mereka lakukan.

\section{Identifikasi Proses Intemalisasi}

Wujud dari peroses dari Internalisasi dalam penelitian ini tergambarkan melalui hasil dari program Ayo Naik Bus yang dilaksanakan oleh Perum DAMRI Bandung. Berdasarkan hasil yang dicapai dari program Ayo Naik Bus ini belum sesuai dengan apa yang diharapkan. Hal tersebut dapat diketahui partisipasi masyarakat Bandung dalan menggunakan bus DAMRI. Dari hasil ini peneliti melihat bahwa masih banyak 
masyarakat Bandung belum mengalami perubahan prilaku dari menggunakan kendaraan pribadi menjadi menggunakan bus, khususnya bus DAMRI Bandung. Penyebab dari kegagalan ini terjadi akibat dari tidak terserapnya objektivitas kepada masyarakat, dalam hal.ini adalah proses penyampaian Program Ayo Naik Bus kepada masyarakat Bandung melalui strategi yang mereka gunakan gagal merubah sudut pandang masyarakat bahwa menggunakan bus lebih baik daripada menggunakan kendaraan pribadi.

Ada faktor yang menjadi penyebab timbulnya hambatan atau masalah yang menjadi penyebab program Ayo Naik Bus ini tidak berjalan dengan baik. Untuk menegatahui apa yang menjadi sebab dari hambatan yang timbul Perum DAMRI melakukan sebuah evaluasi. Evaluasi merupakan bagian dalam 5 tahap pemecahan masalah dalam aktivitas PR. Evaluasi merupakan langkah terakhir yang mencakup penilaian, persiapan, pelaksanaan dan hasil program. Saat program sedang dilaksanakan, dibuat penyesuaian berdasarkan evaluasi umpan balik tentang bagaimana program dalam pelaksanaannya sudahkah berjalan baik atau belum.

Evaluasi aplikasi PR dilakukan untuk mencapai tujuan; (1) memperoleh masukan untuk perencanaan program kegiatan; (2) memperoleh berbagai bahan pertimbangan dalam rangka pengambilan keputusan, layak atau tidak layak program PR untuk dilanjutkan; (3) memperoleh masukanperbaikan program; memperoleh masukan tentang hambatan program yang sedang dilaksanakan; (5) memperoleh masukan untuk perbaikan; (6) memperoleh rekomendasi dan pelaporan terhadap penyandang dana. Berdasarkan NorHadi (dalam Elvinaro, 2011:225).

Berdasakan hasil penelitian yang telah dilakukan peneliti terhadap Perum DAMRI Bandung diketahui bahwa hasil evaluasi tersebut memberikan masukan bagi Perum DAMRI sehingga Perum DAMRI Bandung dapat mengetahui hambatan apa yang sebenarnya terjadi, dengan mengetahui apa yang menjadi penyebab gagalnya sebuah program perusahaan dapat mengambil keputusan untuk mempertimbangkan apakah program yang berjalan masih bisa dilanjutkan atau sebaiknya dihentikan. Dalam kasus ini Perum DAMRI memutuskan untuk menghentikan program yang sekiranya menghambat keberlangsungan perusahaan.

Setelah dilakukan evaluasi diketahui bahwasanya muncul hambatan atau masalah terhadap 
program Ayo Naik Bus yang sedang dilaksanakan ini. Dan akar dari asalah tersebut berasal dari internal dan ekternal Perum DAMRI Bandung.

1. Masalah yang Timbul dari Internal Perusahaan

Sebenarnya Ayo Naik Bus merupakan sebuah kampanye untuk mengajak masyarakat mengunggunakan transportasi publik dari Kementrian Perhubungan yang kemudian didukung oleh pihak-pihak yang terkait termasuk Perum DAMRI salah satunya. Akan tetapi, ketika Perum DAMRI pusatmenyebarkannya ke seluruh kantor wilayahnya untuk mendukung gerakan Ayo Naik Bus, Perum DAMRI cabang Bandung mumutuskan memanfaatkan sosialisasi ini juga sebagai momentum untuk mengembalikan kepercayaan masyarakat Bandung agar kembali menggunakan bus DAMRI. Momentum tersebut dimanfaatkan Perum DAMRI Bandung dengan membuat terobosan-terobosan dan program baru dalam bagian program Ayo Naik Bus.

Anggaran merupakan aspek yang perlu diperhatikan dalam melaksanakan proses dan aspek menajemen PR, menurut Elvinaro Perencanaan anggaran memiliki sejumlah alasan, yakni untuk mengetahui seberapa banyak dana yang diperlukan dalam membiayai suatu program, untuk mengetahui program-program apa saja yang dapat dilaksanakan, untuk mengetahui fungsi anggaran sebagai pedoman atau daftar kerja yang harus dipenuhi, anggaran memaksa disiplin pengeluaran dana sehingga mencegah pemborosan yang tidak perlu, dan melalui anggaran dapat mengetahui apakah dana yang disediakan sudah memadai atau sebaliknya (Elvinaro, 2011:217).

Keterbatasan anggaran menjadi hambatan bagi Perum DAMRI Bandung untuk mengembangkan program ini. Hal ini juga disebabkan karena Perum DAMRI Bandung melaksanakan program Ayo Naik Bus ini tanpa melakukan perencanaan anggran yang baik melihat situasi yang terjadi dimana Perum DAMRI Bandung melakukan program ini tanpa melakukan riset yang rinci terlebih dahulu sehingga tidak dapat memprediksi hambatan seperti apa yang dapat mengancam keberlangsungan program yang mereka jalankan. Sehingga, begitu hambatan muncul sulit bagi Perum DAMRI Bandung untuk mengatasi hambatan tersebut. Padahal menurut Goldblatt (2014:44) riset yang baik akan dapat mengurangi resiko kegagalan. Semakin baik sebuah riset tersebut, maka akan semakin baik 
pula hasil kecocokan tujuan acara dengan hasil acara. Hal ini dapat menentukan kebutuhan, keinginan, kemauan serta ekspektasi dari target sasaran.

Anggaran yang tidak sesuai dengan program yang dijalankan banyak mempengaruhi aktifitasaktifas program, termasuk dalam hal publikasi. Publikasi merupakan hal yang wajarnya dilakukan oleh sebuah perusahaan sebagai media untuk menyampaikan informasi terhadap produk atau kebijakan yang dikeluarkan perusahaan agar pihakpihak yang terlibat baik itu internal atau eksternal perusahan mengetahui.

Akibat dari perencanaan anggaran yang kurang baik Perum DAMRI Bandung tidak dapat melakukan publikasi yang semestinya untuk program Ayo Naik Bus. Publikasi yang dapat dilakukan Perum DAMRI Bandung tidak banyak orang yang mengetahui dan tidak dapat menginformasikan apa yang sebenarnya ingin mereka sampaikan.

2. Masalah yang Timbul dari Eksternal Perusahaan

Hambatan yang dihadapi oleh Perum DAMRI adalah tidak tersampaikan informasi yang ingin mereka berikan kepada masyarakat melalui komunitas Pecinta DAMRI. Komunitas Pecinta DAMRI adalah komunitas yang anggotanya berisikan masyarakat dari berbagai lapisan mulai dari pelajar hingga pekerja yang biasa menggunakan bus DAMRI dan peduli dengan perkembangan bus DAMRI. Pihak Perum DAMRI Bandung sengaja bekerjasama dengan pihak komunitas Pecinta DAMRI karena menganggap mereka dapat menjadi pihak yang dapat menjembatani Perum DAMRI Bandung dengan masyarakat Bandung.

Beberapa pertimbangan yang menjadikan pihak Perum DAMRI Bandung memutuskan untuk bekerjasama pihak komunitas Pecinta DAMRI selain karena anggota mereka yang berasal dari berbagai lapisan masyarakat, juga karena selama ini pihak komunitas Pecinta DAMRI seringkali turut terlibat dalam acara yang diselanggarakan dari pihak Perum DAMRI Bandung. Dari acara-acara tersebut terjalin relasi antara kedua belah pihak yang saling menguntungkan. Menurut Breakenridge (2012:46) cara yang dilakukan oleh Perum DAMRI Bandung ini merupakan aktivitas kolaborasi dan idea sharing yang mana hal ini merupakan sebuah inovasi yang dibutuhkan. Dan dari perspektif komunikasi sangat penting untuk bisa menemukan cara terbaru dalam berkomunikasi dengan stakeholders, baik internal dan eksternal. 
Akan tetapi nyatanya kerjasama denga komunitas Pecinta DAMRI tidak banyak memberikan pengaruh bagi program Ayo Naik Bus, informasi yang disampaikan melalui media sosial komunitas Pecinta DAMRI tidak tersampaikan secara merata kepada seluruh masyarakat Bandung. Informasi yang disebarkan hanya terbatas kepada segilintir orang saja, yakni masyarakat yang telah mengetahui dan mengikuti atau bergabung dengan media sosial komunitas Pecinta DAMRI saja. Selain itu, komunitas Pecinta DAMRI sendiri tidak banyak dikenal oleh masyarakat Bandung sehingga pesan yang ingin diberikan tidak tersalurkan..

Dalam upaya mengatasi hambatan-hambatan yang terjadi dalam program Ayo Naik Bus ini terbentuklah pola komunikasi antara pihak Perum DAMRI Bandung dengan pihak internal dan eksternal perushaan. Menjalin hubungan dengan pihak internal dan eksternal perusahaan merupakan suatu keharusan dalam aktivitas PR. Hubungan dengan publik internal dan eksternal perusahaan dapat memberikan keuntungan bagi perusahaan untuk mencapai targettarget yang sudah mereka tetapkan.

\begin{tabular}{llr}
\multicolumn{2}{c}{ Keterlibatan pihak-pihak } \\
tersebut dibutuhkan & untuk \\
mengambil keputusan yang tepat
\end{tabular}

untuk mengetahui seperti apa kondisi dan situasi tempat program dilaksanakan. Hasil komunikasi dari tiap-tiap pihak sangat bermanfaat bagi upaya Perum DAMRI Bandung mengatasi masalah pada program Ayo Naik Bus ataupun sebagai pelajaran untuk program yang akan dijalankan di masa depan.

1. Pola Komunikasi dengan Internal erum DAMRI.

Dalam komunikasi internal yang terjadi dalam tubuh Perum DAMRI Bandung ini melibatkan antara manajer perusahaan dalam hal ini yakni Manajer Bagian Pemasaran dan Pengembangan Usaha dengan karyawan/staff yang terlibat dalam program Ayo Naik Bus. Pihak manajer perusahaan yang memberikan perintah langsung lewat instruksi-instruksi dan keputusan terkait stratetgi dan taktik seperti apa yang harus dilakukan karyawan dalam program Ayo Naik Bus ini. Sesekali perintah diinstruksikan melalui perantara assisten menajer. Manajer Pemasaran dan Pengembangan Usaha juga menjadi pihak yang bertanggung jawab atas keberlangsungan program ini.

Sementara itu dalam pelaksanaan program ini, karyawan Perum DAMRI Bandung khususnya mereka yang bekerja pada bagian Pemasaran dan Pengembangan Usaha adalah mereka yang terlibat 
langsung dalam program Ayo Naik Bus. Mereka menerima perintah langsung dari manajer untuk melaksanakan instruksi terkait hal apa yang harus dilakukan. Para karyawan ini juga berkewajiban mengumpulkan dan melaporkan tiaptiap data yang masuk ke kantor Perum DAMRI Bandung prihal program Ayo Naik Bus.

Setiap bulanya Perum

DAMRI Bandung mengdakan rapat evaluasi untuk mengetahui laporan kinerja tiap-tiap bagian serta mendengar masukan dari internal mereka sendiri terkait aktivitas perusahaan.Evaluasi per tahun juga dilakukan Perum DAMRI Bandung, tujuannya adalah untuk melaporkan aktivitas perusahaan selama satu tahun penuh, untuk menghitung laba yang didapat perusahaan serta untuk menginfrmasikan kegiatan yang akan dilakukan perusahaan pada tahun berikutnya.

Dalam prakteknya, terdapat dua jenis hubungan internal, yakni, 1) Hubungan Internal-Vertikal, dan 2) Hubungan Internal-Horizontal (Effendy, 2009). Apa yang terjadi di dalam Perum DAMRI Bandung merupakan contoh dari hubungan internal-vertikal.

Apa yang terjadi di dalam tubuh Perum DAMRI Bandung merupakan jenis komunikasi vertikal keduanya. Manajer ataupun karyawan memberikan pandangan mereka terkait dengan aktivitas perusahaan. Akan tetapi, tidak setiap waktu jenis komunikasi bawah ke atas berlangsung, hanya pada saatsaat terntentu seperti rapat internal atau evaluasi saja. Maka dari itu diperlukan pula masukan dari para karyawan untuk memutuskan apa yang yang sebaiknya dilakukan Perum DAMRI untuk menghadapi situasi dimana program yang mereka lakukan memiliki hambatan yang sulit untuk diatasi.

Bentuk komunikasi yang terjadi antara atasan dan bawahan dalam Perum DAMRI Bandung termasuk kedalam jenis komunikasi organisasi. Menurut Deddy Mulyana pengertian komunikasi organisasi adalah komunikasi yang terjadi dalam suatu jaringan yang lebih besar daripada komunikasi kelompok. (Mulyana, 2010:83).

2. Pola Komunikasi dengan Eksternal Perusahaan

Dalam penelitian ini diketahui bahwa yang menjadi publik eksternal Perum DAMRI Bandung dalam program Ayo Naik Bus ini adalah komunitas Ayo Naik Bus dan Dishub kota Bandung.

Hubungan Perum DAMRI

Bandung dengan masing-masing publik eksternalnya memilik jenis hubungan yang berbeda. Masingmasing hubungan antara tiap publiknya memiliki tujuan yang 
berbeda. Hubungan Perum DAMRI

Bandung dengan komunitas Pecinta

DAMRI misalnya, hubungan yang terjalin adalah hubungan eksternal antara perusahaan dengan pelanggannya.

Membina hubungan baik dengan pelanggan, dilakukan agar dapat meningkatkan loyalitas dan kepercayaan pelanggan terhadap produk dan perusahaan itu sendiri. Menurut Seitel (2001:455) tujuan hubungan konsumen antara lain : 1) Mempertahankan pelanggan lama, 2) Menarik pelanggan baru, 3) Memasarkan/memperkenalkan produk atau jasa baru, 4) Memudahkan penanganan keluhan pelanggan, dan 5) Mengurangi biaya. Kegiatan hubungan publik ini dilakukan dalam rangka mengatur dan memelihara hubungan baik dengan para pelanggan agar produk yang dibuat dapat diterima dengan baik oleh para pelanggan.

Hubungan yang terjalin ini penting bagi kelangsungan perusahaan, terlebih hubungan yang terjalin antara perusahaan dengan pemerintah,dalam hal ini hubungan Perum DAMRI dan Dishub, seperti yang diutarakan Elvinaro (2011:110). Hubungan yang terjalin diharapakan terus terjalin dan bertambah erat dengan meningkatkan bentuk kerjasama ke bentuk kerjasama yang lebih intens yang bisa menguntungkan kedua belah pihak, terlebih jika kedua belah pihak tersebut memilki kepentingan di bidang yang sama.

\section{SIMPULAN}

Awal

mula proses pelaksanaan program Ayo Naik Bus berawal dari gagasan Kemenhub, kemudian diimplementasikan oleh Perum DAMRI Bandung menjadi sebuah program dengan cara-cara yang dikemas oleh Perum DAMRI Bandung untuk meningkatkan minat masyarakat Bandung. tujuan alasan mengapa Perum DAMRI Bandung membuat Ayo Naik Bus menjadi sebuah program adalah untuk meningkatkan minat masyarakat Bandung agar mereka menggunakan armada Perum DAMRI lagi sebagai moda transportasi dan secara tidak langsung hal ini dapat mengembalikan kredibilitas Perum DAMRI di mata masyarakat Bandung sebagai moda transportasi publik yang terpercaya.Agar program dapat berjalan dengan baik dan tujuan dapat tercapai, Perum DAMRI membuat strategi berupa pengadaan bus baru, efektifitas pelayanan dan penyebaran informasi melalui publik eksternal perusahaan. Namun, pada program ini hasil yang dicapai adalah berupa kegagalan, karena tujuan dari program yang dilaksankan ini belum tercapai.

Adanya masalah yang menyebabkan tidak berhasilnya 
program Ayo Naik Bus ini. Masalah utama tersebut adalah tidak sempurnanya masayarakat Bandung menerima informasi tentang perubahan perbaikan pelayanan yang dilakukan oleh Perum DAMRI Bandung. Sumber dari timbulnya masalah atau hambatan ini berasal dari internal dan eksternal perusahaan.Masalah yang timbul dari internal perusahaan sendiri yakni disebabkan oleh tidak adanya riset serta minimnya publikasi karena terbatasnya jumlah anggaran yang diterima. Lalu dari masalah yang timbul dari eksternal perusahaan adalah karena komunitas Pecinta DAMRI tidak cukup hanya melakukan penyebaran informasi melalui media sosial saja, terlebih masih banyak juga masyarakat yang belum mengetahui tentang komunitas Pecinta DAMRI itu sendiri. Jadi informasi yang disebar hanya sampai kepada mereka yang memang sudah biasa menggunakan DAMRI dan anggota komunitas mereka saja hal tersbut juga ditambah dengan kondisi lalu lintas kota Bandung yang macet sehingga masyarakat tidak dapat merasakan sepenuhnya peningkatan pelayanan yang dilakukan Perum DAMRI.

Dalam mengatasi hambatanhambatan yang terjadi dalam program Ayo Naik Bus ini peneliti menyimpulkan bahwa pola komunikasi yang dilakukan Perum
DAMRI Bandung mengedepankan komunikasi dua arah antara pihakpihak yang berkaitan, baik itu pihak internal maupun eksternal perusahaan. Komunikasi yang dijalin dimaksudkan untuk menyampaikan perkembangan informasi terkait program yang berjalan agar timbul kesepahaman diantara pihak-pihak tersebut. Berdasarkan hasil evaluasi dan berbagai pertimbangan beberapa strategi program yang berjalan harus dihentikan karena dirasa tidak menguntungkan. Maka cara terbaik bagi Perum DAMRI Bandung mengatasi hambatan yang terjadi adalah dengan cara tidak melanjutkan beberapa kebijakan strategi dalam progam Ayo Naik Bus ini dengan tujuan untuk menghindari perusahaan dari kerugian.

\section{DAFTAR PUSTAKA}

Ardianto, Elvinaro. 2010. Metodologi Penelitian Untuk Public Relations. Bandung: Simbiosa Rekatama Media.

Berger, Peter L. \& Thomas Luckmann 1990. Tafsir Sosial atas Kenyataan: Risalah tentang Sosiologi Pengetahuan (diterjemahkan dari buku asli The Social Construction of Reality oleh Hasan Basari). Jakarta: LP3ES. 
Assumpta, S. Maria. 2002. DasarDasar Public Relatiosn: Teori dan Praktik. Jakarta: Grasindo Berger, Peter L. 1991. Langit Suci: Agama Sebagai Realitas Sosial. Jakarta: LP3ES.

Breakenridge, Deirdre. 2012. Social Media And Public Relations. New Jersey :Publishing as FT Press.

Bungin, Burhan. 2007. Penelitian Kualitatif. Jakarta: PT. Kencana Prenada Media Group. 2008. Metode Penelitian Kualitatif. Jakarta: PT. Raja Grafindo Persada,

Creswell, J. W. 1998. Qualitative inquiry and research design : choosing among five tradition. London : Sage Publication.

Cutlip, Scott M.; Center, Allen H.; Broem, Glen M. 2006. Effective Public Relations. Jakarta: Kencana Pranada Media Group.

Denzin, Norman K. dan Lincoln, Yvonna S. 2009. Handbook of Qualitative Research. Yogyakarta: Pustaka Pelajar.

Effendy, Onong Uchjana. 1998. Hubungan masyarakat. Bandung: PT Remaja Rosdakarya. 2009.

Komunikasi Teori dan Praktek. Bandung : PT Remaja. Rosdakarya.
Glueck W. F., dan Jauch, L. R.. 1999. Manajemen Strategis Dan Kebijakan Perusahaan, alih bahasa : Murad dan AR. Henry Sitanggang, edisi ketiga, Erlangga, Jakarta.

Iriantara, Yosal. 2010. Community Relations. Bandung : Simbiosa Rekatama Media.

Jefkins, Frank. 2004. Public Relations. Jakarta: Erlangga.

Jones, Charles O. 1996. Pengantar Kebijakan Publik (Public Policy. Terjemahan Rick Ismanto).Jakarta :PT RajaGrafmdo Persada.

Luttrell, Regina. 2014. Social Media: How to Engage, Share, and Connect. London: Rowman and Littlefield

Seitel, Fraser. 2001.The Practice of Public Relations. Englewood : Prentice Hall

Moleong, Lexy J. 2006. Metodologi Penelitian Kualitatif. Bandung: PT Remaja Rosdakarya.

Mulyana, Deddy.2007. Metode

Penelitian Komunikasi:

Contoh-Contoh

PenelitianKualitatif dengan Pendekatan PRaktis. Bandung : Remaja Rosdakarya. .2010. Ilmu Komunikasi Suatu Pengantar. Bandung: PT. Remaja Rosdakarya. 
Muhamad, Mufid. 2005. Komunikasi

dan Penyiaran. Jakarta:

Kencana

Persada.

Ruslan, Rosady, 2006. Manajemen

Public Relations Dan Media

Komunikasi, edisi revisi.

Jakarta : PT. Raja Grafindo

Pustaka.

Sanderson, Stephen K. 2003. Makro

Sosiologi. Jakarta : Raja

Grafindo Persada

Seitel, Fraser P. 2001. The Practice

of Publi Relations. Englewood:

Prenctice Hall

Sugiyono. 2009. Metode Penelitian

Kuantitatif Kualitatif dan

$R \& D$. Bandung : Alfabet.

Sumber Lain Dalam Jaringan :

http://digilib.uinsuka.ac.id/11633/1/B

$\mathrm{AB} \% 20 \mathrm{I} \% 2 \mathrm{C} \% 20 \mathrm{IV} \% 2 \mathrm{C} \% 20$

DAFTAR\%20PUSTAKA

http://repository.usu.ac.id/bitstream/h andle/123456789/29235/Chapt

er\%20II.pdf;jsessionid=EAC64 D89D669BB4CEC27AB69BE

CDE1F3?sequence

http://ejournal.ilkom.fisip-

unmul.ac.id/site/wp-

content/uploads/2013/06/eJUR

NAL
Poloma, Margaret M. 2007.

Sosiologi Kontemporer. Jakarta

:PT Raja Grafindo 